\title{
Introduction
}

As soon as a social phenomenon has been fully explained by a variety of converging approaches and is therefore understood in its majestic inevitability and perhaps even permanence, it vanishes ...1

Albert O. Hirschman (1981, p. 134)

\section{OBJECTIVES OF THE BOOK}

Something quite extraordinary took place in the last twenty or thirty years, a rather short period of time in the evolution of economic thought and ideas. $^{2}$ The 'received view' of the 1960s and 1970s about the sources of economic development changed to what amounted to a new conceptual paradigm, that is that incentives and institutions are the key explanatory variables of long term development across countries and even cultures. The theory of incentives appears to be the most important development in economics in the last 40 years (Arrow, 2002) and there is broad consensus that the quality of institutions, more than anything else, determines economic performance over time. According to Douglass C. North 'We cannot understand today's choices without tracing the incremental evolution of institutions' (1990, p. 100). In brief, the new paradigm in the political economy of development and in the economics of politics ${ }^{3}$ is that the 'right' or the 'wrong' institutions emerge from endogenous ${ }^{4}$ and history ${ }^{5}$ determined processes where information asymmetries, ${ }^{6}$ political regimes, ${ }^{7}$ opportunism ${ }^{8}$ and self interested rational ${ }^{9}$ choices $^{10}$ play the most important roles. ${ }^{11}$

Notwithstanding the empirical problems related to measuring the links between the 'right' and the 'wrong' institutions and development, the 'institutions hypothesis' has come to be regarded as the key explanatory variable for overall long term ${ }^{12}$ economic, social and political results across developed and developing countries. Within this context the research agenda of the political economy of institutions and development is not so much to further the notion that institutions matter, or that they influence - and result from - policies, ${ }^{13}$ but to 'unbundle' this finding into its causal effects and into the identification of which institutions - and why - matter the most (Acemoglu, 2005b, p. 1045). ${ }^{14}$ The broad aim of this book is to advance this research agenda by focusing on a particular set of institutions and their 
characteristics and on how the demand for their reform and effectiveness determines - and is determined by - long term economic growth and distributive justice over time.

Within institutions as a whole the macroeconomic institutional arrangements ${ }^{15}$ regulating the interaction and 'coordination'16 between Central Banks, Ministries of Finance and financial sector supervision are considered the most critical ones, ${ }^{17}$ because they determine macroeconomic volatility, affect private and public revenues and expenditures and, hence, provide the overall 18 incentive environment. ${ }^{19}$ But more importantly, they determine macroeconomic performance and growth and hence poverty levels and distributive justice ${ }^{20}$ in general. ${ }^{21}$ An expansive literature perceives poverty, equity 22 and income inequality as strong impediments to pro-growth and even to some modalities of pro-poor reforms. The policy implication is that pro-poor and pro-growth poverty reduction need ${ }^{23}$ to be mutually reinforcing. ${ }^{24}$ In fact, they appear indispensable to each other.

The limited effectiveness of Latin American macroeconomic governance structure has been the most important factor in explaining its long term growth and equity evolution..$^{25}$ On both fronts, on growth and on equity, the record for the region is a dismal one compared to other regions of the world. Although it may have had some fast growth periods, ${ }^{26}$ with the exception of Chile ${ }^{27}$ since the 1990s, Latin America's relative growth record is amazingly slow and volatile. From 1960 to 2000, Latin America's average annual real per capita rate of growth was 1.4 per cent, while Asia's was over 200 per cent faster, at 4.6 per cent. From 1960 to 2002, Latin America had 31 years in which GDP growth was negative or below 1 per cent. The comparable figure for Asia was 15 years. From 1950 to 2001, Latin America's per capita income, as a percentage of that of the United States, came down from 0.28 per cent to 0.22 per cent. In the same period Asia's ratio more than tripled from 0.16 per cent to 0.55 per cent. Between 1900 and 2001, Brazil and Venezuela were the only two countries in the region which saw a rise in their GDP per capita ratio relative to that of the US. More recently, between 1998 and 2003 Latin America's real per capita average annual rate of growth was -0.1 per cent. In 2006, Latin America's Purchasing Power Parity share of the world's GDP was below 7 per cent (about the size of Japan's).

Since the mid-1990s up to 2006 some Latin American countries grew below their potential, faced exchange rate crisis and suffered deep recessions, while others were able to manage their domestic and external macroeconomic challenges better. In spite of some important advances like giving greater independence to Central Banks and much lower inflation rates - there is the overall question of why the region, with the relative exception of Chile, ${ }^{28}$ experienced considerable macroeconomic instability and may still be quite vulnerable to domestic or external adverse 
developments. What explains these different macroeconomic performances? What common domestic or international patterns may there be? Can different macroeconomic institutional characteristics and arrangements explain these differences? What determines the effectiveness of macroeconomic policy 'coordination' 29 in assuring policy consistency? More importantly, there is the need to ascertain the extent to which some of the better specific country economic performances were the result of well anchored political demand for reforms or the results of favorable external ${ }^{30}$ and cyclical factors. ${ }^{31}$

Poverty and inequality have long been a salient feature of Latin America. This region is 'an unfortunate example of historic high concentration of land and the concentration of income associated with exploiting mineral wealth which have left a legacy of limited educational opportunities, a small and state-dependent middle class and a large majority of poor and near-poor households' (Birdsall, 2005a, p. 1). 'Between 1950 and 1970 Latin America was the only region in the world where the share of income going to the poorest 20 per cent of the population consistently declined' (Edwards, 1995, p. 252). 'Inequality in Latin America is higher than in Asia, Eastern Europe and the developed countries' (Ferranti et al., 2004, p. 54). ${ }^{32}$ 'At least since the end of the second world war inequality in Latin America has been much higher than in most parts of the world' (Ferranti et al., 2004, p. 56). Rajan and Zingales (2006, p. 5) aver that the initial distribution of education may well be the most important determinant of inequality. Even after 'controlling' for the level of development, Latin America is a region that suffers from 'excess inequality' 33 when compared to other regions of the world. Fortunately this is changing for the better and in several countries of the region there has been significant decline in poverty levels. However, Gini income coefficients have proven to be much more difficult to reduce.

Macroeconomic volatility ${ }^{34}$ continues to be a major if not the major equity ${ }^{35}$ and development issue and challenge in Latin America (Hausmann and Gavin, 1996, p. 1). Although the recent gains in lower rates of inflation are a very positive development, much more needs to be understood about the underlying factors ${ }^{36}$ and macroeconomic trade-offs before it can be concluded that those gains are sustainable and solidly anchored in fiscal rules. After all, the sustainability of disinflation ${ }^{37}$ depends, to a large extent, on the initial conditions and causes that brought about the lower inflation levels ${ }^{38}$ and on which specific policy responses were adopted by the authorities. It also depends in a fundamental way on the collective learning of what may have brought about the crisis in the first place. This learning experience is the transmission mechanism for information ${ }^{39}$ to illuminate what really matters in social and political processes. 
The macroeconomic volatility problems faced by Latin America which go back well over a century (Singh, 2006, p. 3$)^{40}$ are seldom the result of a lack of technical understanding of the problems faced. As Hausmann and Gavin (1996, p. 1) have so aptly observed:

Latin America is not volatile because it labors under some ancient and ineradicable curse. It is volatile because its institutions and policy regimes have been illequipped to cope with the large shocks that hit the region. This means that policymakers can do much to reduce macroeconomic volatility and its costs, if they focus on building appropriate institutional structures.

The challenge is to find the right 'positive' strategy to nurture a modicum of trust in the 'right' institution and in the market system (Feldstein, 2002, p. 36$).{ }^{41}$

These growth and equity developments are intimately interdependent and influence each other. The slow rates of economic growth are largely explained by macroeconomic volatility which, itself, comes mainly from the existence of growth retarding policies. ${ }^{42}$ These, in their turn, come basically from high poverty levels and inequality, which find a large portion of their origin in macroeconomic volatility and attendant low rates of economic growth. In brief, there are strong distributional implications from macroeconomic performance, ${ }^{43}$ on the one hand, and macroeconomic implications from equity dynamics, trade-offs ${ }^{44}$ and reforms, ${ }^{45}$ on the other. 'Macroeconomic volatility is part of the explanation for the high income concentration' (Williamson, 2003, p. 29). According to Velasco (2006, p. xiv) 'poor growth performance is one reason why populism is once again raising its ugly head in the region.'

It has become well known over the decades that Latin American countries, on the whole, do not save enough, have high fiscal deficits, incur excessive internal and external debt, have the 'wrong' and persistent incentives underpinning the relative ineffectiveness of public (particularly social) expenditures, that total factor productivity (TPF) is low and is growing slowly, and that the region tends to favor protectionism over competition and market forces. In other words, what should change is largely known. What has remained elusive is why those changes and reforms are not fully adopted or end up being insufficient. The key message this book conveys is that a large component of the answer is that reforms are not adopted because there is not sufficient political demand for particular reforms while there is plenty of political support for short term policies that can hardly deliver long term prosperity in terms of faster growth and more distributive justice. Why is this so? Cole et al. (2004, p. 31), blame 'the idiosyncratic and long standing Latin American choices'. But the question still remains: what explains those idiosyncratic choices? 
It is difficult not to conclude that this amounts to a major historical failure, one that should continue to prompt a thorough revision of what this region has been doing and why for the last 50 years. As it will be appreciated, most of the explanation for this abysmal record has to do with the 'initial historical conditions' and the different institutional ${ }^{46}$ and equity ${ }^{47}$ paths followed by these two regions (Sokoloff and Engerman, 2000, p. 218; Acemoglu et al., 2001, p. 1369). This is the key macroeconomic perspective afflicting and challenging Latin America's policy makers, governments and multilateral institutions working in this region of the world.

This overall picture motivates the basic question of why Latin America has not been able or willing to catch up with or not to lose relative weight in comparison to most Western and East Asian countries. This is a major and portentous issue with regional and worldwide economic and political implications. There are two broad tracks in the search for answers to this question. One is to blame external forces, avatars and flaws in the international economic and financial public or private arrangements, and to insist that these problems ought to be changed. The other is to recognize that, although a better international architecture and multilateral environment would help, the most important share of responsibility for the results observed rests with the political and economic policy choices made by politicians and policy makers in the region for well over 50 years.

On these two broad tracks there have been advances. The capacity to blame the external avatars as a way to avoid political accountability is being restricted by a better informed and more discerning public in Brazil, Chile, Colombia, Argentina, Mexico and the region in general. Ideology is losing ground to learning from experience and to the empirics of development. Each country is learning from its own experience, and the endogenous process of institutional transformation is gradually providing better collective rules and incentives. On the other hand, there is worldwide concern and interest in better understanding and managing global capital mobility and international macroeconomic volatility. ${ }^{48}$ There is a growing political interest in the welfare of all citizens of the world. The incentives for this are now more discernible.

Within this global context, the two broad key questions that the book addresses throughout are, first, why are the 'right' combination of propoor and pro-growth reforms often not adopted, delayed ${ }^{49}$ or ultimately ineffective? (Alesina and Drazen, 1991, p. 1171). And, secondly, what are the restrictions that need to be overcome to strengthen the political demand for those policy reforms and for the attendant institutional transformation in developing countries in general and in Latin America in particular? From the start, the key analytical premise is that the answer has more to do with the political demand and tolerance for those reforms than with their 
particular supply-side technical characteristics. The book concludes with and shares - the view that the specific answers to these questions often differ from country to country, from sector to sector, and ultimately depend on the particular idiosyncratic political economy restrictions affecting distinct development situations in different ways. To deal with such heterogeneity an explicit diagnostic approach is necessary. The crucible of reform 'is getting the diagnosis right and addressing the most binding constraints' (Hausmann et al., 2006, p. 13). 'These constraints differ from setting to setting' (Rodrik, 2006, p. 973)..$^{50}$

The perspective is always the demand side of the origin of the most critical reforms and institutions and the emergence of social and political preferences for policy reform. ${ }^{51}$ The book suggests that to unbundle further the institutional hypothesis, there is a need to understand better the causalities between initial conditions of inequality and poverty, on the one hand, and the political demand for the reforms to reduce macroeconomic volatility, on the other. The central theme is the political economy of the demand for policy reform and for institutional transformation. The central premise is 'that the connection between economics and politics is a fundamental part of the development process' (North et al., 2006, p. 4). Needless to say, no originality is claimed at all with this approach. The literature on the political explanation of development is vast, solid and goes back many years. What may be a contribution is to apply it largely to the macroeconomic governance structures, to specific crisis events and to the way in which different recent findings from research strands (like transaction costs) are capitalized to adumbrate how countries can mitigate the effects of political economy factors restricting welfare gains.

Within the context of the broad questions posed above, the more specific objectives of the book are the following: (i) to identify the institutional characteristics which may explain the different macroeconomic performances across countries in Latin America during the last ten years; (ii) through the examination of recent macroeconomic crisis as stress tests in Latin America to discern the real determinants of the demand for the institutions with the potential to deliver macroeconomic performance and distributive justice; and (iii) from the findings for the region as a whole and for each country in particular to draw policy implications and recommendations for policy makers in each country and for multilateral institutions.

Different macroeconomic results such as rates of growth, inflation rates and variability, real exchange rate movements and volatility in general are explained by different institutional characteristics ${ }^{52}$ such as the degree of Central Bank credibility and independence, ${ }^{53}$ the existence of inflation targeting, of effective 'fiscal rules', the information agents have, the depth of 
the financial sector and the strength of its regulatory body, and policy 54 credibility in general. A key institutional characteristic with enormous implications for the effectiveness of macroeconomic policy coordination is the degree to which the relevant 'principals' share a given conceptual paradigm to guide their specific policy postures. ${ }^{55}$ Very high transactions costs can be traced back to differences in those conceptual paradigms. To a large extent the effectiveness of any institutional arrangements is determined by how accurately they can link particular results with specific characteristics. 'In fact, evaluation effectiveness can be judged in terms of its efficiency in identifying public sector institutional obstacles and in contributing to the productive mediation between the demand for and supply of the "right" institutional arrangements' (Wiesner, 1998, p. xiii).

The organizing objective is to discern what the broad political economy strategy could be for Latin America and for some countries to exit from the 'precarious equilibrium' in which they currently seem to find themselves. In effect, Latin America has adopted some key reforms (Lora, 2007, p. 51) $)^{56}$ as inflation targeting, it has dramatically reduced inflation, it has increased tax revenues and it has expanded enormously its social spending in the hope of reducing poverty and inequality. And yet, there is not much political demand and support for some pending critical fiscal, financial and social security reforms. At the same time, the political pressures for even higher - and at times regressive - social spending levels are not abating. The 'tax and spend' policies in some countries have led to high real rates of interest, excessive external financing and exchange rate appreciation. The concern is whether the overall policy framework is really resilient enough to withstand a sudden change in the so far favorable external cycle.

Since an expansive literature has concluded that 'inequality is conducive to the adoption of growth retarding policies' ${ }^{57}$ (Alesina and Rodrik, 1994, p. 465) and that it is 'harmful to growth' (Persson and Tabellini, 1994, p. 600), and we know that economic growth largely explains poverty conditions, the book blends together the following four interdependent components of any development process: (i) macroeconomic performance and volatility; (ii) equity, poverty, social mobility and distributive justice; (iii) fiscal deficits and the redistributive effectiveness of social public expenditures; and (iv) the demand for the 'right' institutions and for policy reform in Latin America. The book builds on findings from different strands of economic research ${ }^{58}$ with the aim of supporting a specific strategy to move forward the process of institutional and policy reform in Latin America.

In a truly seminal work Albert Hirschman (1973, p. 561) warned that political tolerance for inequality depended on poverty levels and expectations (the 
famous 'tunnel effect') and that political support for reforms was conditioned on people's perception of actually benefiting from those reforms. Later on, Alesina and Rodrik (1994, p. 465) asserted that 'inequality is conducive to the adoption of growth retarding policies'. This may be happening in Latin America. Although there have been substantial economic reforms ${ }^{59}$ and progress in the last five years, the region as a whole may have unintentionally cornered itself into a dysfunctional 'bad' equilibrium. Brazil, for instance, has been able to maintain inflation under control, has increased its public expenditures and has made progress in equity issues, but it has not been able to grow fast or to achieve its potential.

Although Latin America may have prevented extreme 'fiscal dominance' and in general has adopted well conceived inflation targeting regimes, it has done so largely through a higher level of taxation, indebtedness and 'a tax and spend damage control' strategy. In this way it has managed to respond to immense political pressures for redistributive social expenditures without incurring major macroeconomic volatility. But this has meant high real rates of interest, and growth rates not fully anchored in long term economic or social infrastructure investment or productivity gains. It has also meant that the fundamental issue of the requirements for social expenditures to actually be redistributive has not been fully addressed. The region, with the possible exception of Chile, is still very vulnerable to external capital market conditions. It is also still vulnerable to political populism.

The current case of Argentina (mid-2007) is somewhat different from that of the region as a whole as this country is still largely in the relatively 'easy stage of recovery' in which fast GDP growth recuperation can mask persistent underlying problems (Teijeiro, 2006). This would be a case of 'dysfunctional convalescence'. For Argentina the key question is whether the post-crisis emerging policy framework has been enriched by the lessons of such calamity (Feldstein, 2002, p. 14). ${ }^{60}$ Most of the collective errors incurred in the developments leading to the crisis, and during the attempts to manage it, may well be redeemed by history if the emerging policy framework incorporates those lessons.

The daunting question for the region is how these modalities of 'dysfunctional' equilibrium will unravel since (i) the pressures for more social expenditure are not abating; (ii) in several countries a portion of those expenditures is actually regressive; (iii) the external favorable economic cycle will recede; and (iv) there is political intolerance for the policy reforms that would untangle the current policy predicament. The aspiration of this book is to add understanding to these challenges by putting together a 'political economy information based strategy' to unlock the current political and policy jinx. 


\section{THE ORGANIZATION AND STRUCTURE OF THE BOOK}

The book is organized around two main parts. Part I contains the Introduction and Chapters 1 and 2. The Introduction summarizes the specific objectives of the book and the conceptual framework on which it is developed. The idea is to underscore early on the relevance of the thematic questions that the book addresses as well as the distinct conceptual premises on which its analysis is built. As will be seen, the specific conceptual premises have been gleaned out of findings from the research agenda of, for example, institutional economics, the politics of policies, incentive theory, transaction costs economics, public choice theory and, in general, from the political economy of pro-growth and pro-poor literature. The Introduction is followed by Chapter 1, which offers an overview summarizing the most relevant and recent macroeconomic developments in Latin America. The idea is to encapsulate the main features of what has happened in the last few years, what has prompted the reforms now in place and what the remaining policy challenges are. These stylized facts have been extracted from the empirical research conducted on the recent experiences of Argentina, Brazil, Chile, Colombia, Costa Rica and Peru.

These six countries were chosen because they were perceived as a 'satisficing sample' where the basic objectives of the research could be pursued better. They combine requirements representing different (i) economic sizes; (ii) macroeconomic policy frameworks; (iii) equity conditions; and (iv) policy responses to sudden stops and to volatility in general. On the whole, the comparative analysis confirms the view that although each country's macroeconomic arrangement is strongly influenced by its own political history, at the bottom of it all compliance with some fundamental core macroeconomic and microeconomic principles are the final determinants of economic performance.

Chapter 2, entitled 'The political economy of macroeconomic policy making in Latin America', provides the broad regional context and possible political economy explanations for the actual policies that end up being adopted. It frames the analysis around the evolution and origins of institutions in general and on how they are mainly the result of endogenous political and equity conditions and perceptions on how public and private markets serve, or not, the public interest. After the core of generally accepted macroeconomic principles is summarized, a perspective on Latin America's macroeconomic and equity performance is presented and placed in the context of the strength or weakness of the political demand for macroeconomic stability and for attendant fiscal and financial reforms. The general conclusion is that short term political interests tend to have a stronger capacity to influence 
public policies than longer term considerations of policy consistency or of the general welfare. This chapter ends offering information and transaction costs based strategy for policy reform and for institutional transformation.

The second part of the book is comprised of six chapters containing the specific country narratives. These country narratives are intended more as political economy perspectives on the reform processes in these countries than as mainstream economic country reports. They should be read within the conceptual context detailed in the Introduction. Each one contains the following:

(i) A political economy diagnostic and entry-point into the recent and current macroeconomic and equity developments;

(ii) an analysis of how the institutional framework responded to a 'stress test' in which macroeconomic stability was challenged by internal or external turbulence. The underlying principle here is that to understand geology one must study earthquakes (Arrow, 1985, p. 321). In other words, to identify the real determinants of the effectiveness of a given macroeconomic policy arrangement, the analysis should focus on a specific macroeconomic crisis because it is then and there that the real characteristics and the predominant incentives of that framework come to the surface;

(iii) A summary of the recent equity developments as there is a growing body of literature linking in dynamic causalities distributive justice with macroeconomic volatility and with the political support for policy reforms.

There are separate notes for each major chapter and for each country narrative. They are integral parts of the text of the book and could be read pari passu as part of the unfolding of its contents. The idea is to provide background to facilitate further reading, and to point out the direction in which the particular research agenda seems to be evolving. The analysis in each country narrative as well as that of the book in general enjoys the benefit of hindsight and nearly full knowledge of ex post developments. It is not intended as a criticism of what policy makers or any institution may have done, right or wrong. It is a heuristic exercise from which to learn and to inform emerging policy.

\section{CONCEPTUAL FRAMEWORK}

The following conceptual premises have been selected from the 'received view' 61 and from the literature to configure the particular political economy 
approaches applied throughout the book: (i) rules are incentives; (ii) macroeconomic stability is part of property rights; (iii) equity is tantamount to equality of opportunity; (iv) macroeconomic volatility is a distributional issue; (v) macroeconomic policy making is a Principal Agent Problem; and (vi) the limits of income induced welfare.

\section{Rules and Incentives as the Path Towards Evaluable History}

Rules are incentives. ${ }^{62}$ They matter because they frame the process through which accountability and the relevant information can be established. But formal or nominal rules ${ }^{63}$ or ad hoc accountability, by itself, matters less than the learning process of discerning the real incentives that influence - reward or sanction - a given individual or collective behaviour. ${ }^{64}$ Accountability requires rules to govern the processes through which attribution, causality or possible association can be established. Just as there are rules governing the separation of powers, which assumes a modality of hierarchical political governance structure and an incentive compatibility framework, there is a need for attendant rules to link ex post results with the ex ante decisions that led to those results. This is the way to build accountability; through 'evaluable history', verifiable (see Laffont and Martimort, 2002, p. 264) baseline and end results scenarios as well as by a 'paper-trail' to inform the process in between. Rules also reduce random or deliberate ambiguity between the intervening factors and actors. In this interaction, accountability and rules spawn the institutional and political incentive structures determining decision-making behavior. That incentive structure is the main determinant of effectiveness. In brief, accountability, rules and incentives need to be understood not as three separate concepts or factors but comprehensively in their mutual interactions and effects.

\section{Macroeconomic Stability as a Property Rights Preserving Institution}

Macroeconomic and price stability are an integral part of 'marketpreserving institutions'. After all, they protect the citizens of a given country from the stealthy - intended or unintended - dissipation of their income and assets. Without the protection of macroeconomic stability, markets can hardly function as money cannot serve as a store of value. It may function as a means of payment, at least in the short run, but not as a credible trustee for savings and investment. At the bottom of it all, in several Latin American countries citizens do not fully trust their local currencies. This is the result of a long history of macroeconomic volatility. In spite of some recent important advances, Latin America's reform agenda 
still has ample room for improvement, especially in the fiscal and financial sector components of macroeconomic policy making in general and of inflation targeting in particular.

\section{Equity and Distributive Justice as Equality of Opportunity}

The concept of equity includes the ideas of fairness perception and distributive justice as processes leading to specific outcomes such as income and wealth. The emphasis is more on the initial conditions and on the processes than on the outcomes or income.

A society with relatively high income inequality might be an equitable society if the observed inequality were the outcome of an entirely fair process - in which some worked harder ${ }^{65}$ or took more economic risks with resultant greater economic gains than others. Equity is sensibly thought of as equality of opportunity and is a more satisfactory concept from a normative point of view; but it is harder to measure. (Birdsall, 2005b, p. 3)

In many developing countries income inequality is the product of inequitable processes. Those results will not be considered politically 'fair' and will lead to meager political support for policy reform and for the development of the 'right' institutions. ${ }^{66}$

\section{Macroeconomic Volatility as a Distributional Issue}

To reduce macroeconomic volatility the political economy of the bidirectional ${ }^{67}$ causal relationships between macroeconomics and inequity need to be unbundled. ${ }^{68}$ After all, macroeconomic volatility is largely a political and distributional issue (Tanzi, 2000, p. 93). Without a strong political demand for macroeconomic stability there will hardly be sufficient political support for the monetary and fiscal policies that deliver such stability. ${ }^{69}$ There will not be sufficient political incentives for the reforms to be really adopted by those who, as rational political actors, will wonder about the viability or wisdom of trying to sell reforms that are not fully shared by the public at large. ${ }^{70}$ And those who think the system is 'unfair' will hardly be willing to wait for growth to lower poverty. 'Inequality is conducive to the adoption of growth retarding polices.' (Alesina and Rodrik, 1994, p. 465). And it could be added that inequality is often also conducive to the 'wrong' pro-poor policies. In brief, political economy restrictions make it very difficult for an 'efficient institutions' solution (Acemoglu, 2005a, p. 4).

To the question of why there is not a Coasean political solution analogous to the economic theorem, ${ }^{71}$ Daron Acemoglu (2003a, p. 2) answers that 
an extension of the Coasean theorem to politics would suggest the answer is no. There are strong empirical and theoretical grounds for believing that inefficient policies and institutions are prevalent. We conclude that these inefficient institutions and policies are chosen because they serve the interests of politicians or social groups that hold political power at the expense of the rest. The theoretical case depends on commitment problems inherent in politics; parties holding political power cannot make commitments to bind their future actions because there is no outside agency with the coercive capacity to enforce such arrangements.

\section{Macroeconomic Policy Making as a Principal-Agent Problem}

If macroeconomic volatility is largely a political economy problem and if politics impacts policies, the question that emerges is which economic model should be applied to understand those political economy ${ }^{72}$ factors $^{73}$ and to be able to influence macroeconomic outcomes? Should it be the neoclassical competitive model? Or should it be one that responds to the characteristics that distinguish macroeconomic policy making? To answer these questions it should be remembered that macroeconomic policy making is a delegated task. ${ }^{74}$ It is not one that markets will autonomously clear or manage. ${ }^{75}$ It implies specialization and division of labor. As such, it involves many of the elements developed by the 'Principal-Agent' framework to deal with delegation and contractarian arrangements in which information asymmetries, ambiguous incentives (Laffont and Martimort, 2002, p. 30) and verifiability problems are so pervasive. It can be said then that macroeconomic policy making is predominantly a 'Principal-Agent' problem, one in which incentives, political and economic, play a major and interdependent role.

As will be seen, for the particular case of Latin America, the challenge that arises is that we are dealing with what could be called an 'absentee principal' who does not seem to be sufficiently politically motivated to demand from its macroeconomic 'agents' macroeconomic stability and low transaction costs to achieve it. This is an asymmetric information problem that unravels into multiple principals, multiple agents and diffused political intertemporal accountability. In brief, macroeconomic policy making in Latin America could be characterized as a 'multiple principal-agent problem' under an ambiguous political accountability context and limited repeated game learning process (Laffont and Martimort, 2002, p. 29). The key policy implication of this characterization is that the strategy to reform macroeconomic arrangements and most institutional frameworks needs to be built on information and incentives in their many modalities of attire.

History, for instance, is information. Beyond the events and causalities involved, history is a major source of information, just as its interpretation 
is a source of information. When it is said that history matters, perhaps the most critical dimension of that importance is the one derived from the information it offers to those who live it, interpret it, or try to learn from it. When we say that history may explain Chile's fiscal conservatism or appreciation for macroeconomic stability, and when it is said that in Brazil the markets are influencing political economy factors and preventing populist inclinations from prevailing, we are saying that in these countries history has informed the public at large about the costs of inflation and about the benefits of macroeconomic stability. History has been the source of information and has engendered a political posture propitious to reform and to macroeconomic stability.

\section{The Limits of Income Induced Welfare}

The basic purpose of the search for the 'right' combination of pro-growth and pro-poor policies is to raise the level of welfare over time of a given country or society in terms of its own particular (bounded) perception of its individual (utility) and collective social welfare function. ${ }^{76}$ This monumental challenge ${ }^{77}$ needs to be parsed out into more specific and, hopefully, more measurable concepts such as income, consumption and other quality of life indexes. This is the task of applied research as well as the goal of public policies. But in the process of interaction between these two fronts the abstract vision of welfare and its metric can get confused. This interplay is now the subject of renewed intense research ${ }^{78}$ to better ascertain under what conditions 'growth without significant greater happiness' should enter a personal or even a collective welfare function (Di Tella and MacCulloch, 2006, p. 26). This is not an irrelevant issue for the search of the 'right' combination of pro-growth and pro-poor policies, or of macroeconomic stability, since at the bottom of both of these themes (growth and equity) lies the fundamental purpose of enhancing individual and collective welfare, as the two appear to be inseparable in any social contract. ${ }^{79}$ Given Latin America's equity imbalance it may well be that gains in social justice ${ }^{80}$ could be a major source of additional welfare (or 'happiness') even without requiring large increases in income. To Rafael Di Tella and Robert MacCulloch (2006, p. 39), 'the potential uses of happiness data in political economy are vast'. It appears to be a major quarry from which to inform public policies. ${ }^{81}$ Within the context of this book and of its main recommendation on the critical role of information in engendering the political demand for the 'right' pro-growth and pro-poor policies, this line

of research is highly welcomed. It should be extended further ${ }^{82}$ into Latin America. 


\section{NOTES}

1. Albert O. Hirschman (1981, p. 134), commenting on the ephemeral nature of analytical or empirical 'discovery', developed the following theorem: 'As soon as a social phenomenon has been fully explained by a variety of converging approaches and is therefore understood in its majestic inevitability and perhaps even permanence, it vanishes'... 'Why things should work this way is left to readers to figure out; just in case they find the proof of my theorem troublesome, they can take heart from the fact that Hegel expressed the same thought less paradoxically and more beautifully when he wrote 'the owl of Minerva spreads its wings only with the falling of dusk'. See his 'The turn to authoritarianism in Latin America and the search for its economic determinants' (Hirschman, 1981).

2. For a review of the development of modern economic thought, see Heilbroner and Milberg (1995).

3. During the last two decades political economics has become one of the most active research areas in the pursuit of better answers for the causes of long term development. Political economics builds on earlier work on public choice theory, game theory, rational choices by economic and political agents, rational expectations, macroeconomics, political cycles, incentive theory and the political economy of asymmetric information.

4. An endogenous process is one in which its results are determined by the interaction of variables within the system in which the process itself takes place. Those variables can, simultaneously or with lagged effects, act as causes and consequences of the observed results. The direction of causality can have stochastic dynamics depending on particular interactions between the factors at play. If institutions result from endogenous social preferences it is difficult to frame the problem in terms of dependent and independent variables and in terms of only explained and explicatory variables. On approaches to deal with this identification problem see Acemoglu et al. (2006).

5. Historian Niall Ferguson finds that the 'nexus between economics and politics is the key to understanding the modern world. But the idea that there is a simple causal link from one to the other - in particular, from capitalism to democracy - is mistaken. One version of the relationship does indeed produce the happy outcome of the capitalist democracy: the double helix of Western development. But like DNA, the cash nexus is capable of mutation. Sometimes democracy can stifle economic growth. Sometimes an economic crisis can undermine a dictatorship. Sometimes democracy can prosper even as the economy flounders. Sometimes growth can strengthen an authoritarian ruler.' (Ferguson, 2001, p. 19).

6. Joseph Stiglitz (2002a, p. 487) posits that 'information affects political process as well as economic ones'.

7. The literature on the relationships between political regimes (democratic or authoritarian) and economic performance is vast, complex and inconclusive. To Daron Acemoglu, democracy may be a critical ingredient for economic growth but 'there is no robust statistical relationship to back it up'. On the other hand, there are different kinds of democracy. Some of them are dysfunctional. Others are quite successful, particularly in protecting rights and in assuring 'creative destruction', which is indispensable for sustained growth (Acemoglu, 2007).

8. Oliver E. Williamson (1996b, p. 378) defines 'opportunism' as follows: 'Self-interest seeking with guile, to include calculated efforts to mislead, deceive, obfuscate, and otherwise confuse. Opportunism should be distinguished from simple self-interest seeking, accordance to which individuals play a game with fixed rules that they reliably obey.'

9. On rational opportunistic models see Alesina et al. (1997). See also Rogoff and Sibert (1988), and Persson and Tabellini (1999).

10. According to Daniel Kahneman and Amos Tversky (1986, p. 68), 'The logic of choice does not provide an adequate foundation for a descriptive theory of decision making'.

11. According to Alesina and Perotti (1994, p. 351), 'Economic policy is the result of a political struggle within an institutional framework'. 
12. Following Baumol, the proximate causes of growth in a given country are basically its capital and investment, labor supply and productivity as well as its capacity for technological change. In 1987, Professor Solow received the Nobel prize for his contribution to growth theory by underscoring the importance of technological change as the factor that can contribute significantly to economic growth even if capital and labor are not increased. The issue, of course, is where does technological innovation come from if it is not from institutions propitious to research and to technological change? The long term causes of growth and equity are the institutions that determine how a society adopts the policies that lead to a given supply of capital and labor productivity.

13. Adam Przeworski (1994, p. 227) warns that 'even if we knew the impact of institutions on policies, we should remain skeptical about institutional prescriptions. What we sorely need is empirical knowledge about what works and what does not: crude facts.'

14. On the challenge of 'unbundling institution' Daron Acemoglu (2005b, p. 1043) insightfully observes that there is a need to go beyond the notion that institutions matter. The real challenge is to ascertain "which specific dimensions of institutions matter for which outcomes. It is only the latter type of knowledge that will enable better theories of institutions to be developed and practical policy recommendations to emerge from this new area. Consequently, the issue of "unbundling institutions", that is, understanding the role of specific components of the broad bundle, is of first order importance.'

15. According to Oliver Williamson (1996, p. 378), an institutional arrangement refers to 'The contractual relation or governance structure between economic entities that defines the way in which they cooperate and/or compete.'

16. The concept 'coordination' is meant here to denote policy making in general as well as deliberate or non-deliberate interaction between Central Banks and Ministries of Finance. On the whole it can be said that in most countries there is a deliberate process of intended or unintended coordination at some point in the budgetary process or in the establishment of inflation targets and monetary rules or policy. To Allan H. Meltzer (2005, p. 145) the word 'coordination' runs the risk of being interpreted within a Keynesian 'model with the implication that monetary and fiscal policy should be coordinated'.

17. According to Kemal Dervis (2006, p. 197), 'for development to work an effective macro strategy is needed. Serious mistakes in macro strategy can be dramatic and create a tremendous amount of damage, as evidenced in the past decades. If the macro strategy is wrong, despite the little bit of help that can be rendered at the project or sector levels, most of the financing is going to go to waste. And worse, unless the financing is in the form of pure grants, it is going to create larger debt for the country.'

18. On the question of which institutions may matter the most see Daron Acemoglu (2005c, p. 1045), 'The question is which economic institutions matter more. Entry barriers? Labor market regulations? Property rights enforcement? Limits on government corruption? These are important, but also very difficult questions. It seems that these questions will be almost impossible to answer with cross-country data alone, and micro data investigations, for example, exploiting differences in regulations across markets and regions appear to be the most promising avenue.'

19. Acemoglu and Robinson (2006a, p. 325) call these 'a cluster of economic institutions' to denote the spread of the extent of some institution 'across a broad section of society'.

20. According to Andrés Solimano (2000, p. 32), 'The modern theory of distributive justice distinguishes between "outside" (or morally arbitrary) factors (gender, race, initial assets, talent) and "personal responsibility" elements (effort, risk-taking attitudes) in shaping the level of income, wealth, and welfare of the individual in society. Social inequality is a reflection of individual differences in these two sets of wealth-creating factors.'

21. Javier Santiso (2006, p. 56) observes that 'macroeconomic volatility has its counterpart in the political and institutional realms, since both reinforce each other'.

22. Following Nancy Birdsall (2005b, p. 3), 'A society with relatively high income inequality might be an equitable society if the observed inequality were the outcome of an entirely fair process - in which some worked harder or took more economic risks with resultant 
greater economic gains than others. Equity is sensibly thought of as equality of opportunity and is a more satisfactory concept from a normative point of view; but it is harder to measure. I argue that in developing countries high money inequality is likely to be a sign of processes that are not equitable.'

23. Although it is difficult to define pro-growth and pro-poor policies precisely, the former can be associated more with capital investment than with, say, employment. The latter can be associated more with 'progressive' public expenditures (for example education, health and other public goods) in the sense that they benefit the poor more than the rich. But these differences are static in nature and dim when a long term view is taken and the respective externalities are subsumed in a general equilibrium process.

24. 'The bidirectional relationship between growth and poverty reduction suggests that ideally consideration of policies should take into account their direct and indirect effects on growth and poverty reduction. This awareness introduces new but necessary levels of complexity in the evaluation of policy options on both agendas.' See p. 11, Chapter 1, 'From vicious to virtuous circles', in Perry et al. (2006).

25. The importance of the effectiveness of macroeconomic management in developed countries is also immense, both in terms of macroeconomic performance as well as a policy framework. In 1933 the US GDP was 31 per cent below its 1929 level. For a history of the evolution of macroeconomic theory and practice see Gregory N. Mankiw (2006, p. 30) and V.V. Chari and Patrick J. Kehoe (2006).

26. Cárdenas Enrique et al. (2000, p. 16) have found that 'Latin American economic performance during the three decades that followed the Second World War was remarkable, inducing a widespread transformation of society. On the one hand, continental GDP grew at 5.6 per cent per year in 1945-1974, or 2.7 per cent per capita.' This pace was not sustained from the 1980 s onwards. In their view, and after certain specific policy flaws are considered, the global explanation for Latin America's lackadaisical performance during the last two decades 'has to do with politics and political economy' (p. 30).

27. Chile's case seems consistent with Olson's (1996, p. 20) observation that 'The fastestgrowing countries are never the countries with the highest per capita incomes but always a subset of the lower-income countries.'

28. Even Chile experienced a negative rate of growth $(-0.8$ per cent $)$ in 1999.

29. According to Richard Cooper (1988, p. 229), 'Coordination can be rule-based or process oriented. Under rule-based coordination, parties agree on certain basic rules concerning the issue at hand and are free to act independently within those rules. Process-oriented coordination, in contrast, involves close consultation on actions to be taken shortly before they are taken'. In practice these two approaches tend to mix but when trying to discern how a given policy decision was taken, the rules or the process approach help establish respective accountabilities. And accountabilities matter.

30. Mauricio Cárdenas and Eduardo Lora (2006, p. 3) 'consider that recent better fiscal results in Latin America are not only the outcome of a propitious business cycle, there is also a genuine effort to manage well the fiscal and debt accounts.'

31. This is a relevant question not only to Latin American countries but also to developed ones. Ben S. Bernanke and Michael Woodford ask 'To what extent are the improvements in performance observed in countries that have adopted inflation targeting the direct result of the change in policy regime, as opposed to other causes? For example, many countries that did not adopt inflation targeting, or adopted only parts of the approach, also experienced substantial improvements in macroeconomic performance in the 1990s. Would these countries have done better if they had adopted full-fledged inflation targeting? Would the inflation-targeting countries have done as well if they had not gone the inflation-targeting route? Are there certain preconditions for inflation targeting to be helpful? Are there institutional or economic circumstances under which adopting inflation targeting can be counterproductive?' (Bernanke and Woodford, 2006, p. 2).

32. Inequality can also afflict developed countries: 'In the United States between 1979 and 1997 the average income of the richest fifth of the population jumped from nine times the income of the poorest fifth to around 15 times. In 1999 Britain income inequality reached its widest level in 40 years'. See The Economist (2001, p. 9). 
33. 'It is sometimes argued that inequality is related to the state of development in a country and comparisons should therefore be made that control for this factor. Londoño and Székely (2000) use regression analysis to compute the difference between actual inequality and expected inequality given the level of development of many countries in the world. The difference for Latin American countries is positive; that is, the region suffers from "excess inequality", which Londoño and Székely (2000) find has fluctuated around 13 Gini points over time.' See Ferranti et al. (2004, p. 54).

34. 'The volatility of Latin America is striking' posit Gavin et al. (1996, p. 4).

35. According to Nancy Birdsall (2005a, p. 2), 'Global markets are inherently disequalizing, making rising inequality in developing countries more rather than less likely.'

36. Guillermo Calvo and Carlos Végh (1999, p. 1605) consider that 'much work remains to be done on the empirical regularities of disinflation'.

37. If disinflations occur because of a possible overshooting of the interest rates and because of a resulting banking and financial crisis, and the underlying fiscal problems have not been fully addressed, then the resurgence of inflation is a highly likely development, although not while the economy is in recession or stagnant.

38. On the question of what makes disinflation sustainable see Marc Hofstetter (2005).

39. The Nobel prizes for the year 2001 were awarded to three eminent scholars who for decades had worked in the field of 'information economics'. All of them felt that information flaws and limitations had not been given adequate relevance in 'completing' the competitive paradigm that 'had dominated economic thinking for two centuries' (Stiglitz, 2002a, p. 486). While it would be difficult to summarize their main policy tenets, four key messages are particularly relevant: (i) information imperfections and asymmetries are pervasive in all economies (Stiglitz, 2002a, p. 469; Akerlof, 2002, p. 413; Spence, 2002, p. 434); (ii) most economic markets are lacking information and political markets tend to be even more informationally deprived; (iii) one of the key roles of the state is to generate information and to support an environment conducive to a growing demand for information; and (iv) information affects political processes as well as economic ones (Stiglitz, 2002a, p. 487).

40. According to Singh (2006, p. 3), 'Over the past century, countries in the Latin American region have demonstrated a marked predisposition toward macroeconomic instability. The region has been unusually prone to bouts of hyperinflation, exchange rate devaluations, failed currency reforms, banking sector collapses, and debt default.'

41. Referring to the political frustration that countries and the IMF often experience when dealing with macroeconomic crisis, Professor Martin Feldstein insightfully observes that the long term country distrust in the market system 'may be the most serious and lasting effects of the crisis' (Feldstein, 2003).

42. Joan Esteban and Ray Debraj (2006, p. 275) aver that 'high inequality will induce voters to support higher degrees of redistribution, thereby inducing heavier distortions on intertemporal resource allocation, specifically dampening investment.'

43. According to Agustin Carstens (2004, p. 4), 'The costs of inflation are borne most heavily by the poor, who lack the wealth needed to diversify into inflation-proof assets.'

44. 'If there were a trade-off between growth and distribution, governments would face tough choices: the welfare-enhancing gains of greater equity could be eliminated by the losses associated with lower growth. In fact, the evidence suggests that the trade-offs work in the other direction. Extreme inequality is not just bad for poverty reduction - it is also bad for growth. Long-run efficiency and greater equity can be complementary. Poor people remain poor partly because they cannot borrow against future earnings to invest in production, the education of their children and assets to reduce their vulnerability. Insecure land rights and limited access to justice can create further barriers to investment.' See UNDP (2005, p. 53).

45. For the social impact of reforms in Latin America during the 1990s see Eduardo Lora (2004, p. 105).

46. According to Mancur Olson (1996, p. 19), 'the large differences in per capita income across countries cannot be explained by differences in access to the world's stock of productive knowledge or to its capital markets, by differences in the ratio of population to 
land or natural resources, or by differences in the quality of marketable human capital or personal culture. Albeit at a high level of aggregation, this eliminates each of the factors of production as possible explanations of most of the international differences in per capita income. The only remaining plausible explanation is that the great differences in the wealth of nations are mainly due to differences in the quality of their institutions and economic policies.'

47. For the developing world as a whole, José Antonio Ocampo (2005b, pp. 1, 6) cautions that 'ignoring inequality in the pursuit of development is perilous. Focusing exclusively on economic growth and income generation as a development strategy is ineffective, as it leads to the accumulation of wealth by a few and deepens the poverty of many.' 'Addressing inequality requires efforts to achieve a balance between many complex, countervailing socio-economic forces. Although economic growth is necessary, it is not a sufficient condition to reduce poverty.'

48. For a serious and well thought out reform proposal for the international monetary system see Stephany Griffith-Jones and José Antonio Ocampo (1998).

49. Alesina and Drazen (1991, p. 1171) argued, in one of the seminal papers on the reasons why reforms are delayed or not adopted, that: 'the timing of stabilizations and, in particular, their postponement cannot be easily understood in terms of models in which the policymaker is viewed as a social planner maximizing the welfare of a representative individual. On the contrary, heterogeneity in the population is crucial in explaining these delays. In many cases, the process leading to a stabilization can be described as a war of attrition between different socioeconomic groups with conflicting distributional objectives. Delays in stabilization arise due to a political stalemate over distribution; stabilizations occur when a political consolidation leads to a resolution of the distributional conflict.'

50. To Dani Rodrik (2006, p. 973), the World Bank's 'Economic growth in the 1990s: Learning from a decade of reform' is 'an extraordinary document demonstrating the extent to which the thinking of the development policy community has been transformed over the years. But there are other competing perspectives as well. One (trumpeted elsewhere in Washington) puts faith on extensive institutional reform, and another (exemplified by the UN Millennium Report) puts faith on foreign aid. Sorting intelligently among these diverse perspectives requires an explicitly diagnostic approach that recognizes that the binding constraints on growth differ from setting to setting.'

51. This approach is different from the 'declining electoral turn out' in many countries which Robert Putnam (2000, p. 404) so aptly examined. The issue here has more to do with the intrinsic policy content of what a political constituency and well organized interest groups will support, than with how many people are going to the polls. The two processes are not totally independent. Over time, the nature of the policy content may influence the turnout, and vice versa, but, at the end of the day, what matters more is what policies become actual legislation. The tenet in this book is that the protection of macroeconomic stability often ends up with scant political demand and electoral support for the policy frameworks that would deliver it.

52. Certain characteristics or key features of public policies are the main determinants of the effectiveness of such policies. Those characteristics include: stability, adaptability, coherence, quality of implementation and enforcement, public support and efficiency. See Ernesto Stein et al. (2005, p. 17).

53. According to Marcela Eslava (2006, p. 49), 'Central Bank independence is a popular recipe to free monetary policy from both inflation bias and the influence of the political cycle. In practice, however, political, philosophical, and economic considerations have moved societies to maintain institutional links between the government and the Central Bank. This gives rise to the question of whether the institutional design of the Central Bank can be adapted to bring out the desired benefits of independence, in an environment in which such independence is, de facto, only partial.

54. Ernesto Stein et al. (2005, p. 16) point out that 'one important characteristic of policies that has been widely recognized in recent work on macroeconomics, trade policy, regulation, and other areas of economics is policy credibility'. 
55. Differences over macroeconomic paradigms are not an exclusive possibility in developing countries. For the differences between two Nobel winners, Robert Solow and George Lucas, on whether 'markets clear' in developed countries, see Gregory N. Mankiw (2006, p. 38).

56. According to Eduardo Lora (2007, p. 51), the 'unbundling of reforms seems to have been the result of governments trying to exploit political spaces, however small, to push change in the desired direction, with the hope perhaps of later generating interest to continue the process.'

57. According to Alberto Alesina and Dani Rodrik (1994, p. 465), 'Inequality is conducive to the adoption of growth retarding policies.'

58. These interdependent strands deal with: (i) the politics of economics, institutions, information and incentives; (ii) transaction costs economics and the endogenous origin of the demand for institutions; (iii) fiscal dominance and the fiscal determination of the price level and volatility; (iv) inflation targeting as an integrated monetary, financial and fiscal policy regime; (v) macroeconomics as a political, information and behavioral problem (Akerlof, 2002, p. 427); (vi) poverty, distributional justice and the perception of social fairness; and (vii) 'Prospect theory' and the determinants of collective decision making processes (Kahneman and Tversky, 1979).

59. For an examination of results of the reforms adopted, see Jeromin Zettelmeyer (2006, p. 18). His overall finding is that the reforms of the 1990s have been good for long-term growth. But much remains to be done.

60. In terms of lessons Martin Feldstein (2002, p. 14) avers that 'a fixed exchange-rate system, even one based on a currency board or other "hard" fix, is a bad idea that is likely to lead to an overvalued exchange rate, a currency crisis, and widespread defaults. A market-determined floating exchange rate is the only way to avoid these problems. Second, substantial foreign borrowing in dollars is a very risky strategy. This is particularly true of short-term debt but is also a problem with longer-term borrowing. It is a problem regardless of whether the borrower is the government or the private sector.'

61. On the evolution of the 'received view' in science and in economics and on how empirical work informs old and emerging paradigms, see D. Wade Hands (2001, p. 95) and his review of the Duhem-Quine 'underdetermination thesis'. According to Hands (2001, p. 96), 'In a nutshell, the Duhem-Quine underdetermination thesis asserts that any scientific theory can be immunized against refuting empirical evidence, that is, that no test is truly definitive. The problem is that no theory is ever tested in isolation.'

62. According to Kenneth J. Arrow (quoted in Laffont and Martimort, 2002), 'The most important development in economics in the last forty years has been the study of incentives to achieve potential mutual gains when the parties have different degrees of knowledge.'

63. Scholars (Buchanan, 1991; Persson and Tabellini, 2004a, p. 94; Rodrik, 2003, p. 10; Acemoglu and Robinson, 2000) use the concept of 'rules' as well as that of institutions as restrictions which can have a formal expression in constitutions and laws as well as in informally accepted norms regulating societal organizations and exchanges. Another line of research relates rules to cooperative and uncooperative 'games'. This approach has spawned the field of game theory and of economic development as a learning 'cooperative game' in which some societies prosper by designing for themselves 'the right' rules (North, 1990; Weingast, 1995; Bardhan, 2001, p. 276) and restrictions.

64. For a discussion of why incentives are not purposely more intensively used see Eduardo Wiesner (2003a).

65. An NBER Working Paper No. 11895 by Peter Kuhn and Fernando Lozano (2006) explains why high wage and income earners work harder. In their conclusion, many salaried men work longer because of an increase in 'marginal incentives'.

66. The issue here is whether inequality is exogenous or not. The premise in this book is that there is a large portion of inequality that is not exogenous and that it depends on some 'controllable' initial factor endowments such as education, health and asset ownership. See Robert Margo (2006, p. 534).

67. Under bidirectional or reverse causality a dependant variable can cause changes in one or more explanatory variables. See Rodney Ramcharan (2006, p. 36). 
68. The political economy of microeconomics (particularly in the labor markets) can also have a substantial adverse impact by retarding recovery and by adding downward inflexibility to the cycle. See Caballero et al. (2004, p. 12).

69. Alejandro Gaviria (2006, p. 20) has pointed out that in Latin America the challenges of growth and equity cannot be tackled in sequence but simultaneously.

70. To deal with these situations 'Clever and determined leadership is needed to overcome such obstacles by creating short-term wins and displaying the courage to take and explain the long-term benefit of reform.' See Ajay Chhibber (2006a, p. xv).

71. Coase's economic theorem holds that 'efficiency will be achieved as long as property rights are fully allocated and that completely free trade of all property rights is possible. The importance of the theorem is in demonstrating that it does not matter who owns what initially, but only that everything should be owned by someone. Trade will place resources in their highest-value occupation eventually.' See Bannock et al. (1989, p. 62).

72. The term 'political economy' seems to have originated in France in the seventeenth century. Sir James Steurt (1761) was the first English economist to put the term in the title of a book on economics, An Inquiry into the Principles of Political Economy. See Drazen (2002, p. 3).

73. In political economy analysis the focus is on the effects of different policy choices on economic outcomes. This contrasts with political science, which tends to concentrate more on the political mechanisms for decision making processes and their respective political outcomes. Under a public choice approach, choice mechanisms are studied using tools of economic analysis. According to Drazen (2000, p. 60), "public choice theory considers not simply the positive and normative aspects of different ways of making collective choices, but also the question of how a society can choose over the set of possible choice mechanism.'

74. See Drazen (2002, p. 22), 'The delegation of decisions to policymakers with different preferences is pervasive in the making of collective choices. In fact, one may argue it is inherent to collective decision making. In any society with a large number of interests, decision making will necessarily be representative, in that individuals will choose representatives to make policy who do not have exactly the same preferences as they do over policies. Not every position can be directly represented, so that delegation in the above sense follows almost automatically from heterogeneity of interests in the population as a whole. The relation between the policies that are chosen and the policies individuals desire will depend on the preferences of the representatives and on the incentives that the voters give them. Hence, from a theoretical perspective, representative politics is an example of a principal-agent problem.'

75. For some of the different equilibrium implications between macroeconomics and microeconomics see Jorge Iván González (2004, p. 75).

76. 'The theory of social choice is preoccupied with the links between individual values and collective choice. The fundamental question is whether - and, if so, in what way - preferences for society as a whole can consistently be derived from the preferences of its members. The answer is crucial for the feasibility of ranking, or otherwise evaluating, different social states and thereby constructing meaningful measures of social welfare or helping public decision making' (Wallace, 2004, p. 6).

77. This is the 'impossibility theorem' idea ascribed to Kenneth Arrow (1951). In essence, the first welfare theorem reads as follows: (i) if there are enough markets, (ii) if all consumers and producers behave competitively and (iii) if an equilibrium exists, then that equilibrium is Pareto optimal. Arrow (1951) and Debreu (1959) concluded that these conditions cannot be met and market failure is the result.

78. Richard Easterlin (1974) was the first economist to pose and to reflect on the question of whether increases in personal income over time actually increased the level of happiness of individuals and of a given society. A related question is which public policies have positive effects on social welfare and actually increase 'happiness'.

79. Perhaps the most influential work in the last 30 years is that of John Rawls, A Theory of Justice (1971), in which he is concerned with the distributive aspects of the basic structure of society. To Rawls the principles of justice are those "that free and rational persons 
concerned to further their own personal interests would accept in an initial position of equality' (p. 11). The 'original position' is a hypothetical situation in which individuals are behind a 'veil of ignorance' about their places in society, that is their assets, attributes, weaknesses, and so on. Since personal differences are unknown and so the future of each one, the 'veil of ignorance' makes possible a collective choice of a particular conception of justice. Rawls posits that two justice principles would be chosen in the original position. 'The first emphasizes equality, including equal rights, liberties, and opportunities. The second principle (later called the difference principle) has been the subject of greater commentary. Rawls himself states this second principle as the general conception of his theory: "All social primary goods - liberty and opportunity, income and wealth and the bases of self-respect - are to be distributed equally unless an unequal distribution of any or all of these goods is to the advantage of the least favored" (p. 303). The difference principle, then, is a maximum rule for the distribution of the goods, material and other, that Rawls regards as primary. The difference principle is the part of Rawls's theory that has generated the greatest volume of hostile reaction and on which, he is generally considered most vulnerable.' See James Konow (2003, p. 1195).

80. The concept of 'social justice' is a complex one. It poses enormous challenges when attempts are made to explicitly translate it into public policies. 'Despite the consensus over the relevance of fairness or of justice, no agreement yet exists among economists or for that matter among psychologists, political scientists, sociologists or philosophers about the proper theory of justice' (Konow, 2003, p. 1189).

81. 'Results based on happiness surveys should be treated critically and cautiously. But the two main alternatives for determining social welfare - either trying to back social welfare out of observed behavior or simply giving up and leaving it to the politicians - surely need to be treated critically and cautiously, too. The patterns observed in the empirical measures of welfare and happiness deserve to play at least some role in the evaluation of what social goals to emphasize, what macroeconomic tradeoffs are acceptable and what public policies are pursued.' See Di Tella and MacCulloch (2006, p. 43).

82. Most of the applied research has been in comparisons between the United States and Europe. See Alesina et al. (2005). 